\title{
First report of shoot blight caused by Diplodia scrobiculata on Pinus halepensis in Tunisia
}

\author{
Sawssen Hlaiem ${ }^{1}$ (1) $\cdot$ Meriem Zouaoui Boutiti ${ }^{1} \cdot$ Mohamed Lahbib Ben Jamaa $^{1}$
}

Received: 29 November 2018 / Accepted: 15 March 2019/Published online: 1 April 2019

(C) Società Italiana di Patologia Vegetale (S.I.Pa.V.) 2019

Keywords Pinus halepensis $\cdot$ Dieback $\cdot$ Diplodia scrobiculata $\cdot$ Pathogenicity

Wilted twigs, branch dieback, necrosis and stem cankers were diffusely observed on Pinus halepensis trees in 2017 in the region of Bizerte "Rimel" (Northen Tunisia). Numerous pycnidia were noticed on the surface of infected branches. To determine the causal agent of the disease, small pieces of stems were surface-sterilized with $3 \%$ sodium hypochlorite, washed in sterile distilled water, placed on potato dextrose agar (PDA) plates and incubated at $25^{\circ} \mathrm{C}$ for 3 to 5 days in darkness. Colonies on PDA of appressed white mycelium darkened with age and turned grey-black after 5 days at $25{ }^{\circ} \mathrm{C}$. Within one week dark pycnidia appeared on pine needles, placed over actively growing cultures incubated in light. Conidiogenous cells were discrete, dark and smooth, with limited percurrent proliferations. Conidia were brown clavate with truncate bases. They were aseptate and some of them developed one to three septa, 34 to $41 \times 11,5$ to $14 \mu \mathrm{m}$. The fungus was morphologically identified as Diplodia scrobiculata (de Wet et al. 2003). Molecular identification was performed by sequencing the internal transcribed spacer (ITS)-rDNA, part of the translation elongation factor $1-\alpha(E F 1-\alpha)$ region and the $\beta$-tubulin genes. BLAST searches of the ITS (MK170175), elongation factor EF-1- $\alpha$ (MK188519) and $\beta$-tubulin (MK188518) sequences, respectively revealed 98\% (KF766160), 97\% (KF766399) and 99\% (DQ458867) identity to Diplodia scrobiculata. Pathogenicity tests were carried out on five 3 -year-old
P. halepensis seedlings grown in plastic pots under natural conditions. A mycelial plug was put in a shallow wound made with a scalpel on the stem foot of each seedling. Sterile PDA plugs were placed into similar wounds on five control seedlings of pine (Linaldeddu et al. 2008). After six weeks all seedlings inoculated with $D$. scobiculata showed symptoms of tip blight and dark brown of the bark and wood tissues in the stem and eventually died. Stem lesions measured $5.7 \pm$ $0.3 \mathrm{~cm}$. The control seedlings remained asymptomatic. The pathogen was successfully re-isolated from inoculated stems, thus fulfilling Koch's postulates. This is the first report of $D$. scrobiculata damages to $P$. halepensis plantations in Tunisia.

\section{References}

de Wet J, Burges T, Slippers B, Preisig O, Wingfield BD, Wingfield MJ (2003) Multiple gene genealogies and microsatellite markers reflect relationship between morphotypes of Sphaeropsis sapinea and distinguish a new species of Diplodia. Mycol Res 107:557-566

Linaldeddu BT, Hasnaoui F, Franceschini A (2008) First report of shoot blight and dieback caused by Diplodia pinea on Pinus pinaster and P. radiata trees in Tunisia. Phytopatol Mediterr 47:258-261

Publisher's note Springer Nature remains neutral with regard to jurisdictional claims in published maps and institutional affiliations.
Sawssen Hlaiem

sawssenhlaiem@gmail.com

1 Institute National of Research Rural Engineering, Water and Forests, B.P.N ${ }^{\circ} 10,2080$ Ariana, Tunisia 